\title{
The Need to Imbue Career Education in Curricula: A Critical Review of National Education Policy of Pakistan
}

\author{
Kanwal Shahbaz ${ }^{1 *}$ and KiranShahbaz ${ }^{2}$ \\ ${ }^{1}$ Centre for Counseling and Career Advisory, National University of Sciences and Technology, Pakistan \\ ${ }^{2}$ University of Technology, Sydney, Australia
}

Submission: July 12, 2017; Published: July 27, 2017

*Corresponding author: Kanwal Shahbaz, Centre for Counseling and Career Advisory, National University of Sciences and Technology, Pakistan; Email: Psykanwal@gmail.com

\begin{abstract}
National Educational Policy (NEP) Pakistan, is the primary source and baseline for the education systems in Pakistan. It has an objective to serve the education industry in a way that all the education sections may work on same standards confirming uniformity in education. It is released by the Ministry of Education (MoE) Pakistan and organized by the advice of the federating units of the government, civil society, universities, officers of MoE and provincial/area education departments, education managers, specialists, academia, teachers, students, parents, and a host of stakeholders including Higher Education Commission, NAVTEC, IED-AKU, AEPAM, PM\&DC \& PEC etc. Its review process was commenced back in 2005 and first paper was finalized in March 2007. The official document comprises of nine chapters and it served as a base line for the development of educational advancements that are exasperated due to the contests and international challenges.
\end{abstract}

\section{Aims and Objectives}

NEP 2009 is reviewed in the light of needs and importance of career education in curriculum for university students that is age group of 18 and above. Furthermore, goals of NEP and implementation of those goals by policy makers in Pakistan will also be observed.

Review of National Educational Policy: The National Educational Policy [1] is reviewed critically to understand the importance of career education in various curricula. It is also reviewed to identify that if the goals of the policy are achieved or are in process. Different clauses and sub points under those clauses have been mentioned lecturing career education in curriculum in multiple ways.

Clause 1.4 Globalization and Competitiveness: It states that "almost all the past educational policies talk about the role of education as a tool of social reform and social development" It further states that this statement is not enough to increase social cohesiveness through education and training. There is a strong need that Educational system should ensure the right of an individual to grow in income and build on the basis of excellence in education and training. According to Graham [2], higher education needs to introduce more chances of getting hired and earn living. But in reality due to lack of opportunities in Pakistan this point has lack of implementation and needs to be addressed seriously on operational grounds and can be achieved through career counseling.

Clause 5.3 Secondary and Higher Secondary Education: Under Policy action the points 5, 6 and 7 addresses the career education conferencing Life skill education, sports activities and provision of counseling lead the concern of career for the young students. It also encourages that students should take up subjects according to their aptitudes that contradicts on the grounds where minimum combination of subjects is offered. Moreover this facility has not been implemented in all the schools of the country. Remote, isolated and backward areas of the country are facing the challenges of education and in such a condition provision of such a facilitative system is far beyond the expectations. It explained that for well-defined career erections, teachers have to be trained so that they can allow the students to move in the right direction for the careers. Policy has failed to access the well trained teachers and has less implication.

Clause 6.3 Quality in Textbooks and Learning material: Under policy action the point 13 states that if librarian is to be taken as profession certain steps has to be taken e.g. improved library services, extension of public libraries, mobile library 
services for rural areas and provision of continuing education for library professionals should be promoted. This point is valid for improving career education via hidden curricula. It has its implication, a lot of work is done in order to improve it and much is still under process.

Clause 6.6 Matching with Labor Market: Including points $1,3 \& 4$ states the importance of career education. It has been introduced via curricula in a way that certain courses have to be a part of curriculum that can fill the gaps between industry and academia. It also focuses on career guidance services for the students if incase certain curricula cannot be pooled.

Curriculum reform: There is a Curriculum reform section. It addresses the careful compilation of curriculum that may contribute to the development process of the learner but may it help in career development specifically, perhaps it is still a question.

Critical Analysis of National Education Policy (2009) of Pakistan: National Educational Policy 2009 is an effective and operative policy with respect to education in Pakistan. It addressed career education in curricula for all the levels of education. The adequate and proper introduction of career education was missing in the policy as per demands of the society. Policy focuses on the progress of healthy citizens of
Pakistan with less concern via curricula on its propagation. Career education has been addressed at secondary and higher secondary level with a challenge of well trained teachers. While considering books and textbooks section hidden curricula addressed career education that means, the textbooks are less helpful in development of children through timeline of career. In the section of matching with the labor market, career education is a major concern. According to the section specific courses have to be taught that may help the learner in labor market that fails due to limited combination of subjects in Pakistan.

Finally curriculum reform sections states that curriculum should be of progressive nature for students instead the link to career education is missing in the policy document. Pakistan as a developing country is encountering issues of low economy, downsizing, workerless factories and lack of wellness and unemployment that may be addressed through career education. In order to deal with the sustainable development goals career education can play a significant role if addressed properly via integrated curricula infused through national educational policy in the official document.

\section{References}

1. Pakistan Ministry of Education (2009) National Education Policy.

2. Graham B, Paul C (2012) Does higher education really lead to higher employability and wages in the RMI?

\section{Your next submission with JuniperPublishers will reach you the below assets}

- Quality Editorial service

- Swift Peer Review

- Reprints availability

- E-prints Service

- Manuscript Podcast for convenient understanding

- Global attainment for your research

- Manuscript accessibility in different formats

( Pdf, E-pub, Full Text, Audio)

- Unceasing customer service

Track the below URL for one-step submission https://juniperpublishers.com/online-submission.php 